\title{
ADP-glucose Pyrophosphorylase Activity in Relation to Yield Potential of Wheat: Response to Independent and Combined High Temperature and Drought Stress
}

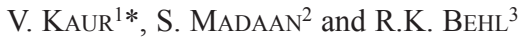 \\ ${ }^{1}$ Germplasm Evaluation Division, ICAR-National Bureau of Plant Genetic Resources, \\ New Delhi-110012, India \\ ${ }^{2}$ Department of Botany and Plant Physiology, \\ ${ }^{3}$ Department of Genetics and Plant Breeding, CCS Haryana Agricultural University, \\ Hisar-125004, Haryana, India
}

(Received 23 August 2016; Accepted 3 November 2016;

Communicated by M. Molnár-Láng)

\begin{abstract}
ADP-glucose pyrophosphorylase (AGPase) activity in the developing grains of two contrasting wheat cultivars WH730 (thermo-tolerant) and UP2565 (thermo-sensitive) was determined in relation to their allosteric effectors and grain growth. The developing grains (35 days after anthesis) were excised from the middle portion of spikes of wheat genotypes subjected to high temperature, drought and their combination at booting, post-anthesis and booting+post-anthesis. The impact of stress treatments was studied by measuring starch content and yield attributes in relation to AGPase activity. AGPase, a key enzyme for starch synthesis, is allosterically activated by 3-phosphoglyceric acid (3-PGA) and inhibited by inorganic phosphate (Pi). Sensitivity of AGPase towards individual and combined high temperature and drought has not been adequately investigated, therefore the present study analyzed AGPase activity, its sensitivity to allosteric effectors under influence of high temperature, drought in order to elucidate the relationship of AGPase with starch accumulation and grain growth. Significant difference in behavior of the enzyme and its allosteric effectors were observed between the two cultivars under high temperature and/or drought. AGPase activity was substantially decreased by high temperature, drought and was found to be positively correlated with the 3-PGA, starch accumulation and yield attributes, while negatively correlated with Pi content. The results showed that effects of high temperature and drought were additive and more severe at booting+post-anthesis stage. Such studies might help in understanding the control mechanisms associated with the pathway of starch biosynthesis and thus provide chemical means to manipulate starch content vis-à-vis grain yield under heat and drought stress.
\end{abstract}

Keywords: Triticum aestivum, stress tolerance, AGPase, allosteric effectors, starch, wheat

Abbreviations: AGPase: ADP-glucose pyrophosphorylase, 3-PGA: 3-phosphoglycerate, Pi: inorganic phosphate, HT: high temperature, D: drought, HT+D: high temperature along with drought, DAA: days after anthesis, DAS: days after sowing, PWP: permanent wilting point, RH: relative humidity

*Corresponding author; E-mails: Vikender.Kaur@icar.gov.in; drvikender@yahoo.in 


\section{Introduction}

Water scarcity and high temperature $\left(>30^{\circ} \mathrm{C}\right)$ at the time of grain filling is one of the major constraints in increasing productivity of wheat in tropical countries like India (Rane and Nagarajan 2004; Zhao et al. 2007; Yan et al. 2008; Kaur and Behl 2010). Grain filling is mainly a process of starch biosynthesis and accumulation. Reduced starch content accounts for most of the reduction in grain dry matter and thus yield (Yang et al. 2004; Sakulsingharoj et al. 2004; Sheikh et al. 2010). Carbon flux into starch is controlled at several steps. Most conspicuous is the reaction catalyzed by ADP-glucose pyrophosphorylase (AGPase) which produces ADP-glucose, the activated glucose form utilized by the polymerizing enzyme starch synthase. AGPase controls the rate-limiting step in starch biosynthesis and is regulated at various levels. Cereal endosperm enzymes, in contrast to other plant AGPases, are particularly heat labile and transgenic studies highlight the importance of temperature for cereal yield (Boehlein et al. 2014). In cereals, manipulation of this enzyme is a prime target to increase starch production during seed development as a means to increase sink strength and, in turn, crop yields. In photosynthetic tissues, the chloroplast-localized AGPase regulates one of the key control points in carbon partitioning between starch and sucrose (Heldt et al. 1977; Preiss et al. 1991; Stitt 1996) as its catalytic activity is governed by the ratio of two small effector molecules; it is activated by 3-phosphoglyceric acid (3-PGA) and inhibited by inorganic phosphate (Pi) (Preiss et al. 1991); as also reported in developing rice seeds (Sikka et al. 2001; Sakulsingharoj et al. 2004) and potato tubers (Sowokinos and Preiss 1982; Sumesh et al. 2008).

However, the AGPase from developing barley (Kleczkowski et al. 1993; Doan et al. 1999) and wheat (Gómez-Casati and Iglesias 2002) is not reported to be activated by 3-PGA and show moderate Pi inhibition which is reversible. Therefore, activation of AGPase by an increasing ratio of 3-PGA to Pi allows the rate of starch synthesis to be adjusted in response to changes in the balance between photosynthesis and sucrose synthesis in leaves (Smidansky et al. 2003) and to changes in the balance between sucrose breakdown and respiration. Allosteric regulation of AGPase by changes in the plastidial concentrations of 3-PGA as activator and $\mathrm{Pi}$ as inhibitor provides a further mechanism for light/dark modulation of starch biosynthesis. Studies in recent past (Wang et al. 2007; Sumesh et al. 2008; Lohot et al. 2010) provide evidence that changes in the allosteric properties of AGPase mediates increased starch production, resulting in increased yields. Accordingly, the thermal stability and regulatory properties of AGPase have received considerable attention. More insight into research was needed to achieve a better understanding of these important aspects of the regulation of starch synthesis as sensitivity of AGPase towards high temperature and drought has not been adequately investigated. The present study therefore analyzed AGPase activity, its sensitivity to allosteric effectors under influence of high temperature, drought and their combination in order to elucidate the relationship of AGPase with starch accumulation and grain growth. 


\section{Materials and Methods}

\section{Plant materials and growing conditions}

Two contrasting spring wheat (Triticum aestivum L.) cultivars WH730 (thermo tolerant) and UP2565 (thermo sensitive) were tested for differential response to high temperature and drought tolerance at 35 days after anthesis (DAA) for AGPase activity, starch accumulation and yield parameters. Plants were raised, without any vernalization treatment, in earthen pots (30 $\mathrm{cm}$ in diameter) lined with polythene bags and each containing $5 \mathrm{~kg}$ of dune sand (Typic Torripsamments) $\left(93.3 \%\right.$ sand $+3.0 \%$ silt $+3.7 \%$ clay, $\mathrm{pH} 8.2, \mathrm{ECe}_{2} 0.8$ $\mathrm{dS} \mathrm{m}{ }^{-1}$ at $25^{\circ} \mathrm{C}, 10.3 \mathrm{mg}(\mathrm{N}) \mathrm{kg}^{-1}, 2.5 \mathrm{mg}(\mathrm{P}) \mathrm{kg}^{-1}, 180 \mathrm{mg}(\mathrm{K}) \mathrm{kg}^{-1}$ ) from 26 November to 15 April (wheat growing season in northern India), under natural conditions of a screen house. After thinning four healthy plants were kept in each bag.

\section{High temperature and water deficit treatments}

The experiment was resolved into $2 \times 4 \times 3$ [(two genotypes, four treatment levels, viz. control, high temperature (HT) stress, drought (D) and combined (HT + D) stress, three stages of treatment imposition (booting, post-anthesis and booting + post-anthesis)] complete randomized design (CRD). Control conditions comprised of growing plants at field capacity $(20-22 \%)$ and ambient temperature $\left(10-26^{\circ} \mathrm{C}\right)$ during crop growth. High temperature stress was given to plants by shifting the pots to polyhouse for one week with maximum temperature $5-8^{\circ} \mathrm{C}>$ than the ambient. Drought was imposed by withholding water supply till permanent wilting point (PWP, gravimetric soil moisture 6-7\%) was attained. The plants were re-irrigated (600 $\mathrm{ml}$ water per pot to attain field capacity) after PWP. Combined stress was given to plants by shifting pots to polyhouse for one week and simultaneously drought conditions were maintained by withholding water supply. The plants of both varieties of wheat were exposed to high temperature, drought and the combination of both stresses at booting stage (70 DAS); post-anthesis stage (10 DAA) and booting + post-anthesis stage. The soil moisture was almost similar in both varieties under all treatments. Temperature in general was higher in polyhouse $\left(5-8^{\circ} \mathrm{C}\right)$ than the screen house. The light intensity, though not measured, was adequate under screen house and polyhouse conditions to permit sufficient photo-synthetically active radiation.

\section{Sampling}

Mother shoots in all the bags were tagged during spike emergence and labeled ears of each treatment were sampled at 35 DAA and stored in liquid nitrogen for estimation of AGPase, 3-PGA and Pi. The control and stressed plants were harvested for yield components at maturity. Number of grains $5 \mathrm{spike}^{-1}$, grain weight $5 \mathrm{spike}^{-1}(\mathrm{~g})$, grain yield plant $^{-1}(\mathrm{~g})$ and 1000-grain weight $(\mathrm{g})$ was recorded for each of the three replicates in both varieties. 


\section{Extraction and estimation of AGPase}

AGPase (EC 2.7.7.23, mmol NADP reduced min $^{-1} \mathrm{~g}^{-1}$ grain $\mathrm{FW}$ ) was extracted following method of Savitch et al. (2000) by grinding two basal grains from the middle spikelets of the liquid nitrogen frozen wheat spikes (35 DAA) in pestle and mortar using $2 \mathrm{ml}$ buffer having $50 \mathrm{mM}$ MOPS ( $\mathrm{pH} 7.5$ ), $5 \mathrm{mM} \mathrm{MgCl}_{2}, 1 \mathrm{mM}$ EDTA, $0.02 \%$ (w/v) BSA, $2 \%$ (w/v) polyvinylpyrrolidone (PVP), $2.5 \mathrm{mM}$ DTT and $0.05 \%(\mathrm{w} / \mathrm{v})$ Triton X-100. After centrifugation of homogenate for $1 \mathrm{~min}$ at $15,000 \times g$ (Remi refrigerated centrifuge; model C-30), supernatant was separated and used for enzyme assay.

AGPase was assayed in reverse direction by modified method of Kleczkowski et al. (1993). One $\mathrm{ml}$ of reaction mixture containing $50 \mathrm{mM}$ MOPS ( $\mathrm{pH} 7.4$ ), $7.5 \mu \mathrm{mol}$ of $\mathrm{MgSO}_{4} \cdot 7 \mathrm{H}_{2} \mathrm{O}, 3 \mu \mathrm{mol}$ of 3-PGA, $0.5 \mu \mathrm{mol}$ of NADP ${ }^{+}, 0.5 \mu \mathrm{mol}$ of ADP-glucose, 2 units of phosphoglucomutase and 2 units of glucose-6-phosphate dehydrogenase was incubated with $100 \mu \mathrm{l}$ of enzyme extract. The reaction was started by the addition of $200 \mu \mathrm{l}$ of sodium pyrophosphate $(2.5 \mu \mathrm{mol})$. The pyrophosphorolytic activity of AGPase was assayed spectrophotometrically (Systronic India Spectrophotometer-117) by monitoring the increase in absorbance due to conversion of NADP to NADPH at $340 \mathrm{~nm}$.

\section{Extraction and estimation of allosteric effectors}

3-PGA and Pi were extracted by the method of Stitt (1990). Basal grains from the middle spikelets of liquid nitrogen frozen wheat spikes were thoroughly washed and grinded in a chilled mortar and pestle with $5.0 \mathrm{ml}$ extraction medium. For preparation of $252 \mathrm{ml}$ extraction medium, $72 \mathrm{ml}$ chloroform, $144 \mathrm{ml}$ methanol and $36 \mathrm{ml}(50 \mathrm{mM} \mathrm{NaF}, 20.0 \mathrm{mM}$ EDTA, $50 \mathrm{mM}$ HEPES) and a pinch PVP was added during grinding of samples. The extract was centrifuged at $7000 \times g$ for 10 min at $0-4{ }^{\circ} \mathrm{C}$. The supernatant was thoroughly mixed with $4.0 \mathrm{ml}$ distilled water on a cyclomixer and allowed to stand for $10 \mathrm{~min}$ to have phase separation. After proper separation, upper layer (methanol) containing metabolites were dried at $35 \pm 1{ }^{\circ} \mathrm{C}$ in vacuum with rotatory evaporator and the residue was dissolved in $4.0 \mathrm{ml}$ distilled water.

3-PGA was estimated following method of Latzko and Gibbs (1972) by coupling two reactions of glycolytic pathway to reduce 3-PGA to glyceraldehyde 3-P consuming stiochiometric amount of ATP and NADH and oxidation of NADH is followed at $340 \mathrm{~nm}$. To the standard assay mixture in a final volume of $1.0 \mathrm{ml}$ containing $0.1 \mathrm{ml}$ of tris-EDTA buffer ( $0.4 \mathrm{M}$ in $0.4 \mathrm{M}$ EDTA, $\mathrm{pH} 7.6)$, test extract, $20 \mu \mathrm{l}$ of $5 \mu \mathrm{M}$ NADH, $0.1 \mathrm{ml}$ of 50 $\mu \mathrm{M}$ ATP, $20 \mu \mathrm{l}$ of $0.5 \mathrm{M} \mathrm{MgCl}_{2}, 1$ unit of glyceraldehyde-3-PDH and 1 unit of 3-PGA kinase, $50 \mu \mathrm{l}$ glycerate $3-\mathrm{P}$ dehydrogenase $(0.05 \mathrm{U})$ was added and change in absorbance recorded at $340 \mathrm{~nm}$ with time interval of 1 second (time scan). Changes in absorbance during linear phase were determined. Inorganic phosphate was estimated by method of Ozbun et al. (1973). Concentration of $\mathrm{Pi}\left(\mu \mathrm{mol} \mathrm{g} \mathrm{g}^{-1}\right.$ grain FW) was calculated using standard curve prepared with $1-10 \mathrm{mg} \mathrm{ml}^{-1} \mathrm{KH}_{2} \mathrm{PO}_{4}$.

Starch content ( $\mathrm{mg} \mathrm{g}^{-1} \mathrm{DW}$ ) was estimated by the method of Clegg (1956). Protein content (\%) in grain was estimated by Infratec 1241 Grain Analyser, Foss (USA). Also, 
seedling stage peptide profile in response to high temperature (HT), drought (D) and dual stress $(\mathrm{HT}+\mathrm{D})$ outlined via SDS electrophoresis of leaf extracts was done. These findings have been reported earlier by Kaur et al. (2014).

\section{Statistical analysis}

Data were analyzed statistically using complete randomized design (CRD) with three replicates performing analysis of variance (ANOVA) using Statistical Analysis Package (SAS 2011; version 9.2) for each stress imposition stage (booting, post-anthesis, booting + post-anthesis) separately. Means were tested by LSD at $\mathrm{P}_{0.05}$ level $\left(\mathrm{LSD}_{0.05}\right)$ and significance of differences among treatments and genotypes were determined.

\section{Results}

All the stress treatments either individually applied HT, D or combined HT + D led to a decrease in the mean AGPase activity in both the genotypes, however decline was more in UP2565 compared to WH730. Significant decline in the activity of AGPase was observed in UP2565 when the stress treatments were imposed at post-anthesis as well as booting + post-anthesis stage indicating the severity of stress and sensitivity of the genotype (Table 1). Similar trend was observed in starch content, thus correlating it well to AGPase activity. Few other reports also confirmed these results earlier (Geigenkerger et al. 1998; Ahmadi and Baker 2001; Smidansky et al. 2002; Ballicora et al. 2004; Sumesh et al. 2008). Lower mean value of 3-PGA was observed in grains of UP2565 (4.56) relative to WH730 (5.60). Stress treatments reduced 3-PGA content (exception in UP2565 at booting stage, where the data showed little increase compared to the control) and the trend of increase/decrease in AGPase activity in both the varieties was similar to that of 3-PGA. Higher value of Pi in grain was observed in WH730 (112.13 $\mu \mathrm{mol} \mathrm{g}^{-1}$ grain FW)

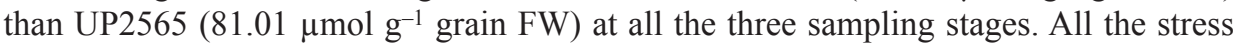
treatments increased Pi concentration with interaction of HT + D leading to the maximum increase. More increase in Pi content was observed in UP2565 (more than 1.5-fold) than WH730 due to combined stress imposed at booting + post-anthesis stage which can be attributed to the corresponding decrease in the starch content and hence grain yield in var. UP2565 over WH730. Results supporting the negative effect of Pi concentration on starch synthesis were also presented by Geigenkerger et al. (1998), Slattery et al. (2004) and Lohot et al. (2010).

Water scarcity combined with high temperature decreased yield components substantially in tested wheat genotypes (Table 2). Overall the effects of high temperature and drought were additive and more detrimental effects were observed with the combined stress imposed at booting + post-anthesis stage. Interaction of HT $+\mathrm{D}$ resulted in more decline in yield and yield related parameters in UP2565 than WH730 compared to individually applied stress treatments. Tolerant genotype WH730 had higher grain yield, grain number 5 spike ${ }^{-1}$, grain weight 5 spike $^{-1}$ and 1000 -grain weight under control conditions and it maintained yield potential under stress conditions as indicated by less 
Table 1. Effect of individually applied high temperature (HT), drought (D) and combined (HT+D) stress imposed at different stages on the activities of ADP-glucose pyrophosphorylase (AGPase; mmol NADP reduced $\mathrm{min}^{-1} \mathrm{~g}^{-1}$ grain FW), 3-phosphoglyceric acid (3-PGA; $\mu \mathrm{mol} \mathrm{g} \mathrm{g}^{-1}$ grain FW), inorganic phosphate $\left(\mathrm{Pi} ; \mu \mathrm{mol} \mathrm{g} \mathrm{g}^{-1}\right.$ grain $\left.\mathrm{FW}\right)$ and starch content $\left(\mathrm{mg} \mathrm{g}^{-1} \mathrm{DW}\right)$ in the grains of wheat genotypes at 35 DAA

\begin{tabular}{|c|c|c|c|c|c|}
\hline \multirow{2}{*}{ Enzyme/metabolite } & \multirow{2}{*}{ Genotype } & \multicolumn{4}{|c|}{ Booting stage } \\
\hline & & $\mathrm{C}$ & HT & $\mathrm{D}$ & $\mathrm{HT}+\mathrm{D}$ \\
\hline \multirow{2}{*}{ AGPase } & WH730(T) & $9.87^{\mathrm{A}}$ & $9.22^{\mathrm{AB}}$ & $8.8^{\mathrm{ABC}}$ & $8.53^{\mathrm{ABC}}$ \\
\hline & UP2565(S) & $8.42^{\mathrm{BC}}$ & $8.25^{\mathrm{CD}}$ & $8.21^{\mathrm{CD}}$ & $8.15^{\mathrm{CD}}$ \\
\hline \multirow{2}{*}{ 3-PGA } & WH730(T) & $5.60^{\mathrm{A}}$ & $5.52^{\mathrm{A}}$ & $5.41^{\mathrm{AB}}$ & $5.15^{\mathrm{ABC}}$ \\
\hline & UP2565(S) & $4.56^{\mathrm{B}}$ & $4.59^{\mathrm{B}}$ & $4.73^{\mathrm{BC}}$ & $4.58^{\mathrm{B}}$ \\
\hline \multirow{2}{*}{$\mathrm{Pi}$} & WH730(T) & $112.13^{\mathrm{A}}$ & $121.11^{\mathrm{AB}}$ & $119.75^{\mathrm{AB}}$ & $123.94^{\mathrm{AB}}$ \\
\hline & UP2565(S) & $81.01^{\mathrm{E}}$ & $91.05^{\mathrm{DE}}$ & $87.63^{\mathrm{E}}$ & $106.35^{\mathrm{CD}}$ \\
\hline \multirow{2}{*}{ Starch } & WH730(T) & $881.22^{\mathrm{A}}$ & $859.57^{\mathrm{AB}}$ & $856.35^{\mathrm{AB}}$ & $810.52^{\mathrm{C}}$ \\
\hline & UP2565(S) & $851.48^{\text {B }}$ & $832.52^{\mathrm{BC}}$ & $822.00^{\mathrm{BC}}$ & $795.13^{\mathrm{E}}$ \\
\hline \multirow{2}{*}{ Enzyme/metabolite } & \multirow{2}{*}{ Genotype } & \multicolumn{4}{|c|}{ Post-anthesis stage } \\
\hline & & $\mathrm{C}$ & HT & $\mathrm{D}$ & $\mathrm{HT}+\mathrm{D}$ \\
\hline \multirow{2}{*}{ AGPase } & WH730(T) & $9.87^{\mathrm{A}}$ & $9.46^{\mathrm{AB}}$ & $8.82^{\mathrm{ABC}}$ & $7.94^{\mathrm{CD}}$ \\
\hline & UP2565(S) & $8.42^{\mathrm{BC}}$ & $7.69^{\mathrm{CD}}$ & $7.56^{\mathrm{CD}}$ & $6.40^{\mathrm{D}}$ \\
\hline \multirow{2}{*}{ 3-PGA } & WH730(T) & $5.60^{\mathrm{A}}$ & $5.09^{\mathrm{AB}}$ & $5.14^{\mathrm{AB}}$ & $5.04^{\mathrm{AB}}$ \\
\hline & UP2565(S) & $4.56^{\mathrm{B}}$ & $4.54^{\mathrm{B}}$ & $4.39^{\mathrm{BC}}$ & $4.36^{\mathrm{BC}}$ \\
\hline \multirow{2}{*}{$\mathrm{Pi}$} & WH730(T) & $112.13^{\mathrm{A}}$ & $128.34^{\mathrm{AB}}$ & $125.58^{\mathrm{AB}}$ & $142.16^{\mathrm{B}}$ \\
\hline & UP2565(S) & $81.01^{\mathrm{E}}$ & $105.66^{\mathrm{CD}}$ & $100.93^{\mathrm{D}}$ & $127.73^{\mathrm{B}}$ \\
\hline \multirow{2}{*}{ Starch } & WH730(T) & $881.22^{\mathrm{A}}$ & $782.61^{\mathrm{C}}$ & $768.99^{\mathrm{C}}$ & $706.00^{\mathrm{D}}$ \\
\hline & UP2565(S) & $851.48^{\mathrm{B}}$ & $779.22^{\mathrm{C}}$ & $677.57^{\mathrm{E}}$ & $660.78^{F}$ \\
\hline \multirow{2}{*}{ Enzyme/metabolite } & \multirow{2}{*}{ Genotype } & \multicolumn{4}{|c|}{ Booting + Post-anthesis stage } \\
\hline & & $\mathrm{C}$ & HT & $\mathrm{D}$ & $\mathrm{HT}+\mathrm{D}$ \\
\hline \multirow{2}{*}{ AGPase } & WH730(T) & $9.87^{\mathrm{A}}$ & $9.10^{\mathrm{AB}}$ & $8.50^{\mathrm{AB}}$ & $7.95^{\mathrm{BC}}$ \\
\hline & UP2565(S) & $8.42^{\mathrm{BC}}$ & $6.99^{\mathrm{D}}$ & $7.12^{\mathrm{D}}$ & $6.09^{\mathrm{E}}$ \\
\hline \multirow{2}{*}{ 3-PGA } & WH730(T) & $5.60^{\mathrm{A}}$ & $5.04^{\mathrm{AB}}$ & $5.08^{\mathrm{AB}}$ & $4.92^{\mathrm{C}}$ \\
\hline & UP2565(S) & $4.56^{\mathrm{B}}$ & $4.18^{C}$ & $4.06^{\mathrm{C}}$ & $3.80^{\mathrm{D}}$ \\
\hline \multirow{2}{*}{$\mathrm{Pi}$} & WH730(T) & $112.13^{\mathrm{A}}$ & $143.16^{\mathrm{B}}$ & $138.57^{\mathrm{B}}$ & $158.34^{\mathrm{C}}$ \\
\hline & UP2565(S) & $81.01^{\mathrm{E}}$ & $117.57^{\mathrm{B}}$ & $129.88^{\mathrm{C}}$ & $138.93^{\mathrm{C}}$ \\
\hline \multirow{2}{*}{ Starch } & WH730(T) & $881.22^{\mathrm{A}}$ & $730.17^{\mathrm{C}}$ & $745.25^{\mathrm{C}}$ & $690.24^{\mathrm{D}}$ \\
\hline & UP2565(S) & $851.48^{\mathrm{B}}$ & $704.87^{\mathrm{D}}$ & $688.96^{\mathrm{D}}$ & $603.83^{\mathrm{E}}$ \\
\hline
\end{tabular}

Statistical comparison was among wheat genotypes within each treatment imposition stage separately. Means with at least one letter common are not statistically significant at $\mathrm{P}_{0.05}$ level using Fisher's Least Significant Difference.

C - Control; HT - High temperature; D - Drought; HT + D - High temperature combined with drought; T - Tolerant; $\mathrm{S}$ - Susceptible. 
Table 2. Effect of individually applied high temperature (HT), drought (D) and combined (HT + D) stress on yield $(\mathrm{g})$ and yield attributes in the grains of wheat genotypes at different stages of treatment imposition

\begin{tabular}{|c|c|c|c|c|c|}
\hline \multirow{2}{*}{$\begin{array}{c}\text { Yield and } \\
\text { yield attributes }\end{array}$} & \multirow{2}{*}{ Genotype } & \multicolumn{4}{|c|}{ Booting stage } \\
\hline & & $\mathrm{C}$ & HT & $\mathrm{D}$ & $\mathrm{HT}+\mathrm{D}$ \\
\hline \multirow{2}{*}{$\begin{array}{l}\text { Grain weight } \\
5 \text { spike }^{-1}\end{array}$} & WH730(T) & $7.13^{\mathrm{A}}$ & $6.77^{\mathrm{AB}}$ & $6.56^{\mathrm{AB}}$ & $6.13^{\mathrm{B}}$ \\
\hline & UP2565(S) & $6.03^{\mathrm{B}}$ & $5.86^{\mathrm{B}}$ & $6.03^{\mathrm{B}}$ & $5.09^{\mathrm{C}}$ \\
\hline \multirow{2}{*}{$\begin{array}{l}\text { Grain number } \\
5 \text { spike }^{-1}\end{array}$} & WH730(T) & $170.00^{\mathrm{A}}$ & $173.33^{\mathrm{A}}$ & $139.67^{\mathrm{BC}}$ & $153.00^{\mathrm{B}}$ \\
\hline & UP2565(S) & $150.67^{\mathrm{B}}$ & $132.67^{\mathrm{CD}}$ & $122.33^{\mathrm{D}}$ & $125.33^{\mathrm{CD}}$ \\
\hline \multirow{2}{*}{$\begin{array}{l}\text { Grain yield } \\
\text { plant }^{-1}\end{array}$} & WH730(T) & $3.53^{\mathrm{A}}$ & $3.28^{\mathrm{A}}$ & $3.34^{\mathrm{A}}$ & $3.21^{\mathrm{A}}$ \\
\hline & UP2565(S) & $3.08^{\mathrm{AB}}$ & $2.92^{\mathrm{BC}}$ & $2.85^{\mathrm{BC}}$ & $2.71^{\mathrm{BC}}$ \\
\hline \multirow{2}{*}{1000 -grain weight } & WH730(T) & $41.94^{\mathrm{A}}$ & $39.16^{\mathrm{ABC}}$ & $39.06^{\mathrm{ABC}}$ & $37.32^{\mathrm{BCD}}$ \\
\hline & UP2565(S) & $40.58^{\mathrm{AB}}$ & $39.72^{\mathrm{BC}}$ & $38.81^{\mathrm{BC}}$ & $36.84^{C}$ \\
\hline \multirow{2}{*}{$\begin{array}{c}\text { Yield and } \\
\text { yield attributes }\end{array}$} & \multirow{2}{*}{ Genotype } & \multicolumn{4}{|c|}{ Post-anthesis stage } \\
\hline & & $\mathrm{C}$ & HT & $\mathrm{D}$ & $\mathrm{HT}+\mathrm{D}$ \\
\hline \multirow{2}{*}{$\begin{array}{l}\text { Grain weight } 5 \\
\text { spike }^{-1}\end{array}$} & WH730(T) & $7.13^{\mathrm{A}}$ & $6.55^{\mathrm{AB}}$ & $6.66^{\mathrm{AB}}$ & $6.04^{\mathrm{BC}}$ \\
\hline & UP2565(S) & $6.03^{\mathrm{B}}$ & $5.67^{\mathrm{BC}}$ & $5.27^{\mathrm{CD}}$ & $4.79^{\mathrm{D}}$ \\
\hline \multirow{2}{*}{$\begin{array}{c}\text { Grain number } 5 \\
\text { spike }^{-1}\end{array}$} & WH730(T) & $170.00^{\mathrm{B}}$ & $186.33^{\mathrm{A}}$ & $156.67^{\mathrm{C}}$ & $189.00^{\mathrm{A}}$ \\
\hline & UP2565(S) & $150.67^{\mathrm{C}}$ & $147.67^{\mathrm{C}}$ & $149.00^{\mathrm{C}}$ & $100.00^{\mathrm{D}}$ \\
\hline \multirow{2}{*}{$\begin{array}{l}\text { Grain yield } \\
\text { plant }^{-1}\end{array}$} & WH730(T) & $3.53^{\mathrm{A}}$ & $2.94^{\mathrm{B}}$ & $2.75^{\mathrm{BC}}$ & $2.68^{\mathrm{BC}}$ \\
\hline & UP2565(S) & $3.08^{\mathrm{AB}}$ & $2.35^{\mathrm{CD}}$ & $2.37^{\mathrm{CD}}$ & $2.20^{\mathrm{D}}$ \\
\hline \multirow{2}{*}{ 1000-grain weight } & WH730(T) & $41.94^{\mathrm{A}}$ & $38.78^{\mathrm{B}}$ & $38.47^{\mathrm{B}}$ & $36.86^{\mathrm{CD}}$ \\
\hline & UP2565(S) & $40.58^{\mathrm{AB}}$ & $38.47^{\mathrm{BC}}$ & $37.94^{\mathrm{BC}}$ & $35.30^{\mathrm{D}}$ \\
\hline \multirow{2}{*}{$\begin{array}{c}\text { Yield and } \\
\text { yield attributes }\end{array}$} & \multirow{2}{*}{ Genotype } & \multicolumn{4}{|c|}{ Booting + Post-anthesis stage } \\
\hline & & $\mathrm{C}$ & HT & $\mathrm{D}$ & $\mathrm{HT}+\mathrm{D}$ \\
\hline \multirow{2}{*}{$\begin{array}{l}\text { Grain weight } 5 \\
\text { spike }^{-1}\end{array}$} & WH730(T) & $7.13^{\mathrm{A}}$ & $5.70^{\mathrm{B}}$ & $5.50^{\mathrm{BC}}$ & $5.36^{\mathrm{BC}}$ \\
\hline & UP2565(S) & $6.03^{\mathrm{B}}$ & $5.53^{\mathrm{BC}}$ & $4.64^{\mathrm{D}}$ & $3.96^{\mathrm{D}}$ \\
\hline \multirow{2}{*}{$\begin{array}{c}\text { Grain number } 5 \\
\text { spike }^{-1}\end{array}$} & WH730(T) & $170.00^{\mathrm{A}}$ & $145.67^{\mathrm{BC}}$ & $154.33^{\mathrm{B}}$ & $140.33^{\mathrm{C}}$ \\
\hline & UP2565(S) & $150.67^{\mathrm{BC}}$ & $109.33^{\mathrm{D}}$ & $103.33^{\mathrm{D}}$ & $102.00^{\mathrm{D}}$ \\
\hline \multirow{2}{*}{$\begin{array}{l}\text { Grain yield } \\
\text { plant }^{-1}\end{array}$} & WH730(T) & $3.53^{\mathrm{A}}$ & $2.71^{\mathrm{BC}}$ & $2.69^{\mathrm{BC}}$ & $2.47^{\mathrm{CD}}$ \\
\hline & UP2565(S) & $3.08^{\mathrm{AB}}$ & $2.40^{\mathrm{CD}}$ & $1.98^{\mathrm{CD}}$ & $1.83^{\mathrm{D}}$ \\
\hline \multirow{2}{*}{ 1000-grain weight } & WH730(T) & $41.94^{\mathrm{A}}$ & $37.07 \mathrm{CD}$ & $37.32^{\mathrm{CD}}$ & $36.68^{\mathrm{CD}}$ \\
\hline & UP2565(S) & $40.58^{\mathrm{AB}}$ & $35.95^{\mathrm{C}}$ & $35.16^{\mathrm{C}}$ & $33.09^{\mathrm{D}}$ \\
\hline
\end{tabular}

Statistical comparison was among wheat genotypes within each treatment imposition stage separately. Means with at least one letter common are not statistically significant at $\mathrm{P}_{0.05}$ level using Fisher's Least Significant Difference.

C - Control; HT - High temperature; D - Drought; HT + D - high temperature combined with drought; $\mathrm{T}$ - tolerant; $\mathrm{S}$ - susceptible. 
Table 3. Relationship of mean ADP-glucose pyrophosphorylase (AGPase) activity and starch content in wheat grains at 35 DAA with yield parameters and allosteric effectors of AGPase

\begin{tabular}{|l|c|c|}
\hline \multicolumn{1}{|c|}{ Correlation with } & $\begin{array}{c}\text { ADP-glucose pyrophosphorylase } \\
\text { (AGPase) activity }\end{array}$ & Starch content \\
\hline ADP-glucose pyrophosphorylase (AGPase) & 1 & $0.811^{* *}$ \\
\hline Grain yield plant ${ }^{-1}$ & $0.861^{* *}$ & $0.928^{* *}$ \\
\hline 1000 grain weight & $0.798^{* *}$ & $0.895^{* *}$ \\
\hline 3-phosphoglyceric acid (3-PGA) & $0.888^{* *}$ & $0.686^{* *}$ \\
\hline Inorganic phosphate (Pi) & $-0.427^{*}$ & $-0.461^{*}$ \\
\hline
\end{tabular}

The * and ** indicate correlation significance at the $\mathrm{P}_{0.05}$ and $\mathrm{P}_{0.01}$ levels of probability, respectively.

reduction in comparison to susceptible genotype, UP2565. These results suggested that higher thermo-sensitivity of UP2565 was related to decreased starch synthesis in this variety indicating WH730 was better performing variety under heat and drought conditions. Few other reports also confirmed that reduced starch content accounts for most of the reduction in grain dry matter and thus yield (Zahedi et al. 2003; Yang et al. 2004; Sakulsingharoj et al. 2004; Sheikh et al. 2010).

The correlations of activities of enzyme AGPase and starch content examined with grain growth and allosteric effectors of AGPase (3-PGA and Pi) were analyzed (Table 3). A positive and highly significant correlation $\left(\mathrm{P}_{0.01}\right)$ of mean AGPase activity with starch accumulation $(r=0.811)$, 3-PGA $(r=0.888)$, grain yield $(r=0.861), 1000$-grain weight $(\mathrm{r}=0.798)$ was observed in tested wheat cultivars, while it was negatively and significantly correlated with $\mathrm{Pi}$ content $\left(\mathrm{r}=-427, \mathrm{P}_{0.05}\right)$. Similar results were obtained for correlations of starch content with grain yield, 3-PGA and Pi content. A significant correlation of AGPase activity with starch accumulation, grain yield and 1000-grain weight indicates that enhancing the activities of the enzymes would lead to increase in starch accumulation and thus grain growth.

\section{Discussion}

A study in wheat endosperm by Gómez-Casati and Iglesias (2002) reported that inhibition of the purified AGPase by Pi, ADP and fructose-1, 6-bis-phosphate could be reversed by 3-PGA. Sakulsingharoj et al. (2004) reported a mutant AGPase independent of 3-PGA activation and resistant to Pi inhibition may enhance starch synthesis and consequently seed weight in rice. Research studies in potato (Stark et al. 1992; Sumesh et al. 2008), wheat (Smidansky et al. 2002; Lohot et al. 2010); rice (Sikka et al. 2001; Smidansky et al. 2003; Sakulsingharoj et al. 2004) and maize (Wang et al. 2007) provide evidence that changes in the allosteric properties of AGPase mediates increased starch production, resulting in increased yields. Our study also supports these earlier results as more concentration of 3-PGA in var. WH730 could have paved way for more AGPase activity by inhibiting Pi in comparison to thermo-sensitive UP2565 (Table 1). More increase in Pi content was observed in UP2565 (more than 1.5-fold) than WH730 due to combined 
$(\mathrm{HT}+\mathrm{D})$ stress can be attributed to the corresponding decrease in the starch content and hence grain yield in var. UP2565 over WH730. Results for effect of stress treatments imposed at all mentioned stages for protein content in grains as well as peptide profiles in leaf samples have been reported earlier (Kaur et al. 2014). Due to stress treatments, protein content showed considerably less reduction per se, however significant changes in peptide profile outlined via SDS electrophoresis of leaf extracts of seedlings exposed to HT, D and combined HT + D stress were observed which revealed the emergence of several new peptides with persistence of few original ones indicating their chaperoning activity and possible role in stress adaptation (Kaur et al. 2014). In the present study, the effects of high temperature and drought were additive with more severe effects on enzyme activity and yield components when combined stress was imposed at booting + postanthesis. The enzyme activity, starch content and yield parameters appear to be much less affected at booting stage which may happen due to acclimation. Thus, the differential sensitivity of AGPase to allosteric effectors is of particular significance in finding allosterically insensitive AGPase. Expressing an efficient AGPase insensitive to regulation by 3-PGA and Pi in wheat would possibly lead to faster starch accumulation and early and relatively prolonged filling of grains and thus avoid extreme terminal high temperature experienced during later part of grain development as well as water scarcity. Knowledge of the mechanisms by which sugars regulate grain set under drought and high temperature conditions could be exploited in wheat breeding for abiotic stress tolerance/climate change.

\section{References}

Ahmadi, A., Baker, D.A. 2001. The effect of water stress on the activities of key regulatory enzymes of the sucrose to starch pathway in wheat. Plant Growth Regul. 35:81-91.

Ballicora, M.A., Iglesias, A.A., Priess, J. 2004. ADP-glucose pyrophosphorylase: a regulatory enzyme for plant starch synthesis. Photosynth. Res. 79:1-24.

Boehlein, S.K., Shaw, J.R., Georgelis, N., Hannah, L.C. 2014. Enhanced heat stability and kinetic parameters of maize endosperm ADP-glucose pyrophosphorylase by alteration of phylogenetically identified amino acids. Arch. Biochem. Biophys. 543:1-9.

Clegg, K.M. 1956. The application of anthrone reagent to the estimation of starch in cereals. J. Sci. Food Agr. 7:40-44.

Doan, D.N.P., Rudi, H., Olsen, O.A. 1999. The allosterically unregulated isoform of ADP-glucose pyrophosphorylase from barley endosperm is the most likely sources of ADP-glucose incorporated into endosperm starch. Plant Physiol. 121:965-975.

Geigenkerger, P., Gerger, M., Stitt, M. 1998. High temperature perturbation of starch synthesis is attributable to inhibition of AGPase by decreased levels of glycerate 3-phosphate in growing potato tubers. Plant Physiol. 117:1307-1316.

Gómez-Casati, D.F., Iglesias, A.A. 2002. ADP-glucose pyrophosphorylase from wheat endosperm. Purification and characterization of an enzyme with novel regulatory properties. Planta 214:428-434.

Heldt, H.W., Chon, C.J., Maronde, D., Herold, A., Stankovic, Z.S., Walker, D., Kraminer, A., Kirk, M.R., Heber, U. 1977. Role of orthophosphate and other factors in the regulation of starch formation in leaves and isolated chloroplasts. Plant Physiol. 59:1146-1155.

Kaur, V., Behl, R.K. 2010. Grain yield in wheat as affected by short periods of high temperature, drought and their interaction during pre- and post-anthesis stages. Cereal Res. Commun. 38:514-520. 
Kaur, V., Mahla, R., Behl, R.K. 2014. High temperature, drought and their interaction induced protein alterations in sensitive and tolerant wheat varieties. Electron. J. Plant Breed. 5:641-650.

Kleczkowski, L.A., Villand, P., Luthi, E. Olsen, O.A., Preiss, J. 1993. Insensitivity of barley endosperm ADPglucose pyrophosphorylase to 3-phosphoglycerate and orthophosphate regulation. Plant Physiol. 101:179186.

Latzko, E., Gibbs, M. 1972. Measurements of intermediates of photosynthetic carbon reduction cycle using enzymatic method. In: Pietro, A.S. (ed.), Methods of Enzymology. Academic Press. New York, USA. pp. 261-268.

Lohot, V.D., Sharma-Natu, P., Pandey, R., Ghildiyal, M.C. 2010. ADP-glucose pyrophosphorylase activity in relation to starch accumulation and grain growth in wheat cultivars. Curr. Sci. 98:426-430.

Ozbun, J.L., Hawker, J.S., Greenberg, E., Lamelli, C., Priess, J. 1973. Starch synthase phosphorylase, ADPglucose pyrophosphorylase and UDP-glucopyrophosphorylase in developing maize kernels. Plant Physiol. 51:1-9.

Preiss, J., Hutney, J., Smith-White, B., Li, L., Okita, T.W. 1991. Regulatory mechanisms involved in the biosynthesis of starch. J. Pure Appl. Chem. 63:535-544.

Rane, J., Nagarajan, S. 2004. High temperature index for field evaluation of heat tolerance in wheat varieties. Agr. Syst. 79:243-255.

Sakulsingharoj, C., Choi, S.B., Hwang, S.K., Edwards, G.E., Bork, J., Meyer, C.R., Preiss, J., Okita, T.W. 2004. Engineering starch biosynthesis for increasing rice seed weight: the role of the cytoplasmic ADP-glucose pyrophosphorylase. Plant Sci. 167:1323-1333.

SAS 2011. The SAS system for Windows. Release 9.2., SAS Institute, Cary, NC, USA.

Savitch, L.V., Harney, T., Huner, N.P.A. 2000. Sucrose metabolism in spring and winter wheat in response to high irradiance, cold stress and cold acclimatization. Physiol. Plant. 108:270-278.

Sheikh, S., Sikka, V.K., Behl, R.K., Kumar, A. 2010. Grain growth rate and grain yield in relation to ADPglucose pyrophosphorylase activity in wheat (Triticum aestivum L. em. Thell) under normaland late sown conditions. Cereal Res. Commun. 38:589-599.

Sikka, V.K., Choi, S.B., Kavakli, I.H., Sakulsingharoj, C., Gupta, S., Ito, H., Okita, T.W. 2001. Subcellular compartmentation and allosteric regulation of the rice endosperm ADP-glucose pyrophosphorylase. Plant Sci. 161:461-468.

Slattery, C.J., Kavakli, H.I., Okita, T.W. 2004. Engineering starch for increased quantity and quality. Trends Plant Sci. 5:291-298.

Smidansky, E.D., Clancy, M., Meyer, F.D., Lanning, S.P., Blake, N.K., Talbert, L.E., Giroux, M.J. 2002. Enhanced AGPase activity in wheat endosperm increases seed yield. Proc. Natl. Acad. Sci. 99:1724-1729.

Smidansky, E.D., Martin, J.M., Hannah, L.C., Fisher, A.M., Giroux, M.J. 2003. Seed yield and plant biomass increases in rice are conferred by deregulation of endosperm ADP-glucose pyrophosphorylase. Planta 216:656-664.

Sowokinos, J.R., Preiss, J. 1982. Pyrophosphorylases in Solanum tuberosum III. Purification, physical and catalytic properties of ADP-glucosepyrophosphorylase in potatoes. Plant Physiol. 69:1459-1466.

Stark, D.M., Timmerman, K.P., Barry, G.F., Preiss, J., Kishore, G.M. 1992. Regulation of the amount of starch in plant tissues by ADP-glucose pyrophosphorylase. Science 258:287-292.

Stitt, M. 1990. Fructose 2, 6 bisphosphate. In: Leo, P.J. (ed.), Methods in Plant Biochemistry. Academic Press, New York, pp. 87-92.

Stitt, M. 1996. Metabolic regulation of photosynthesis. In: Baker, N.R. (ed), Photosynthesis and the Environment. Kluwer Academic Publishers, Dordrecht, The Netherlands, pp. 151-191.

Sumesh, K.V., Sharma-Natu, P., Ghildiyal, M.C. 2008. Starch synthase activity and heat shock protein in relation to thermal tolerance of developing wheat grains. Biol. Plant 52:749-753.

Wang, Z., Chen, X., Wang, J., Liu, T., Liu, Y., Zhao, L., Wang, G. 2007. Increasing maize seed weight by enhancing the cytoplasmic ADP-glucose pyrophosphorylase activity in transgenic plants. Plant Cell Tissue Organ Cult. 88:83-92.

Yan, S.H., Yin, Y.P., Li, W.Y., Li, Y., Liang, T.B., Wu, Y.H., Geng, Q.H., Wang, Z.L. 2008. Effect of high temperature after anthesis on starch formation of two wheat cultivars differing in heat tolerance. Acta Ecologica Sinica 28:6138-6147. 
Yang, J., Zhang, J., Wang, Z., Xu, G., Zhu, Q. 2004. Activities of key enzymes in sucrose to starch conversion in wheat grains subjected to water deficit during grain filling. Plant Physiol. 135:1621-1629.

Zahedi, M., Sharma, R., Jenner, C.F. 2003. Effect of high temperature on grain growth, metabolites and enzymes of starch synthesis pathway in grains of two wheat cultivars differing in their response to temperature. Funct. Plant Biol. 30:291-300.

Zhao, H., Dai, T., Jing, Q., Jiang, D., Cao, W. 2007. Leaf senescence and grain filling affects by post-anthesis high temperatures in two different wheat cultivars. Plant Growth Regul. 51:149-158. 